\title{
Under the background of cultural creative industry development private colleges art exploration of innovative personnel training
}

\author{
Xianyuan $\mathrm{Wei}^{1 \text {, a }}$ \\ ${ }^{1}$ Jiangxi Institute of Fashion Technology, Jiangxi, Nanchang, 330201 \\ a417484171@qq.com
}

Keywords: Culture creativity; Art; Innovative talents

\begin{abstract}
Innovation is the basic power, existence and development of a country and national innovation ability raise cannot leave the popularization and development of innovation education in university education. Under the background of cultural creative industry development, strengthen the perspectives of artistic innovation personnel training is very important. Entrepreneurship in this paper, the culture industry under the background of the function of art creative talents are simple to describe, and combined with the existing problems in private colleges art innovative talent training, and puts forward some countermeasures and Suggestions for improvement.
\end{abstract}

\section{The introduction}

The science and education practice in our country and the strategy of reinvigorating China through human resource development, the development of cultural creative industry has become the inevitable trend, in this background, private colleges art will be how to cultivate creative talents, in order to realize the demand of social development, how to abandon the past behind deviation on the understanding and the teaching idea, in order to promote art innovative development of cross-cutting, is that we need to deep thought.

\section{Cultural creative industry and interactive art creative talents}

Art creative talents for the development of cultural creative industry. Art of the development of innovative talents as the foundation of cultural creative industry provides the knowledge and ability, is the important pillar of cultural creative industry. First of all, the cultural creativity development cannot leave the art creative talents to join, because of the cultural creative industry started relatively late, and with the traditional cultural differences, in the absence of predecessors' guides, art creative talented person's demand will be relatively high; Second, art creative talents relying on it to be of high quality, comprehensive talents resources, multidisciplinary, innovative concept, in a wide range of areas for the market development of cultural creative industry created the basic conditions. Because in art creative talents training in colleges and universities in China is not perfect, makes the high quality art culture innovative talents shortage in our country, thus inhibiting the development of cultural creative industry. As an emerging industry, the fundamental driving force of the development of the innovation and entrepreneurship to make it, if the lack of originality, just rely on imitation and replication, the cultural creative industry cannot be long-term development.

Culture creative industry innovative talent training in art. Cultural creative industry based on the field demand of talents, to provide professional teachers and teaching equipment, and innovative ideas into the college of education concept, cultivate innovative talents to provide important art help for colleges and universities.

The improvement of the school-running thoughts to colleges and universities. On the traditional ideas of private universities, students learned to accumulate more attention, and ignore the cultivation of students' practical ability, to allow students in social life, difficult to meet the requirement of the enterprise, its professional ability literacy talents caused social demand and supply are not corresponding. And the development of cultural creative industries can effectively 
improve the educational philosophy will be clear to the social demand to colleges and universities, wants to cultivate comprehensive art creative talents.

Encourage improved discipline in universities. At present, our country many private colleges teaching course are very similar, content is also a lack of diversity, willing to give up without clear identification between college professional, excellent professional is not prominent, for teaching to cultivate art talents, tend to be single, confined to generic class teaching, and the lack of professionalism.

To improve the cultivation model of colleges and universities. Private colleges is different from public schools, the art college of art talent training mode which can be roughly divided into two kinds: the first is to focus on cultivating talents, the traditional art of cultivating a group of creative talents. The training mode of talents is suitable for the traditional career model, and with the constant development of social and economic circumstances, the traditional career mode is bound to be a hit, has been replaced with the new model, and this kind of talents will also challenged; The second is to completely abandon the traditional mode of talent training, according to the market demand, attaches great importance to the economy and the implementation of the industrial value. The personnel training mode is given priority to with actual demand, in entering the society after graduation, can quickly adapt to the enterprise culture and enterprise needs, can quickly create economic value for the enterprise. Therefore, the development of cultural creative industries is designed to improve the latter mode of talent training, make it more in line with the market demand.

University teaching staff construction. Whatever the talent cultivation, is inseparable from the teacher, can't depart from the support of a strong faculty. In developing innovative society, the cultural industry rapid rise today, the construction of the teachers also need to follow the pace of The Times development, and constantly from thought, professional knowledge and professional skills to strengthen the training, so as to realize the purpose to help provide students with a strong teaching.

\section{Private colleges art problem analysis of innovative personnel training}

Art education be utilitarian. Art education is different from other education, pay attention to the development of culture, connotation, quality education, but for the moment, commercialization and marketization of art education phenomenon is serious, the performance of these 'tropism is art education. The emergence of this phenomenon also makes higher art education run by the local field suffered significant impact, destroy the art education of original value.

The lack of artistic ethics. Art education is not only a technical education, but also culture. The ethical education. But at present, many private colleges blindly pay attention to training students art technology ability, rather than on the ethical education, course content and the proportion is the best performance. Art have lack of ethics, without thought, like the person lost instincts.

Ignore the social relations. Private colleges in innovation ability training for students, the students learning, for the most part, limited in the campus, in order to avoid and reduce the communication and trouble with social enterprise, many private colleges are not willing to cooperate with enterprises, too much which makes students lose a lot of chance to practice and practice during the period of school to enterprises. This neglect education mode and social relationship, will lead to students lack the necessary experience, often free from reality, art is still comes from life, private colleges not ignore the importance of society to the students.

The political thought of indifference. Art education is not isolated, in the process of art creative talents cultivation, the artistic creation are not limited to personal ideas, many art creators are immersed in their own world, and neglect the concern for social and political, lofty ideals of the pursuit, is a kind of lonely. The causes of this phenomenon mainly has two aspects, the first is the social corruption, abuses, making art students, negative attitude, although in jinping rampant improved after President came to power, but for a long time to correct the understanding of the concept; Second, the bondage of traditional art thoughts, think don't participate, away from the political life is the respect and trust of our party, but also can enjoy their rights and stable. 
The backward education idea. Private colleges as school teachers team is different from that of the public schools, education concepts behind can also see from two aspects: the first is the teacher of innovation concept is relatively backward, most teachers are treated with traditional education, the traditional teaching methods and knowledge skills ingrained, the art of art teachers are due to have its own technology is relatively rich, pay attention to the practice of the skills in the process of teaching, or teaching and teaching, and ignore the innovation education, the cultural creativity industry era of rapid development, technical art talent already cannot use development needs. The second is the innovation of school education concept, curriculum innovation is less, to give students innovation development platform are few and far between, too much emphasis on classroom teaching rather than social practice, lack of the innovative talents in cultivated.

Institutional arrangements for divorced from reality. Most private class in China art colleges and universities on the system arrangement, the transfer system of professional, lack of flexibility, not enough human, enrollment system is still considered the idea of "a youngster", and on the system of student participation in scientific research project, is not a complete, scientific and systematic system, weak school scientific research atmosphere, students with poor academic ability, innovation ability, as a result of not ideal.

Disconnect between teaching department. Education work should be clear guidelines and specific management responsible for the part, most of the provinces autonomous regions in China art colleges is limited by many factors in the teaching department cannot realize the exchange, makes a number of resource waste, right segmentation, mutual disconnect between the department of education resource utilization rate is low, affect the construction of faculty and students of art innovation ability.

\section{Private colleges art countermeasures of innovative personnel training}

Clear art creative talent training goal . Aimed at the problem mentioned in the training target is not clear phenomenon, private colleges the first thing to do is clear objectives, clear art creative talents training target, system, structure, executable, indicate the direction for the construction of art cultivation system.

Correct "art creative talents is equal to the skilled personnel" training objectives. Past long dominated by the traditional personnel training mode, pay attention to skilled personnel, under the background of cultural creative industry, its correct to cultivate innovative talents of art can start from the two points: first of all, in many ways much correct school, teachers, parents, students and other people in the society of art creative talents of misunderstanding and prejudice, emphasize quality standard; Second, the government take measures to improve subjective art creative talents of social status, can through the project construction or revision of the laws and regulations, borrow the necessity of media publicity and innovation.

Clear the role of the private art colleges and universities. Private universities on teaching contents, methods and objective requirement with ground while putting aside differences, according to their own school-running resources determine its social responsibility, to clear the development direction of art innovative talent cultivation, outstanding professional advantages and characteristics, and effective use of the local government to give help, according to the market demand, realize the goal of talent training and the social development.

With the combination of humanity quality education. Art the cultivation of innovative talents cannot ignore the humanity quality education, humanistic quality education of inclusiveness, of innovative personnel training has very important significance. So, the school when arranging courses to combine two closely, to provide comprehensive high-quality art creative talents for the society.

To strengthen the students' moral quality cultivation. The problems mentioned in the society, art, the lack of political ethics, how to improve this mainly depends on schools and government 
coordination, on the one hand is extended school teaching ethics course, to give students more learning related the opportunity and way of ethical quality, on the other hand is that the government regulation of social ethos, the perfection of relevant laws and regulations, and strong execution.

Highlight art power of innovative talents training. For private colleges their own problems, improvement scheme of non-state-run universities, in the concept of talent cultivating outstanding personalized and comprehensive, in the student evaluation system continuously show comprehensive and fair, in the education teaching management, and realizing mutual sharing unceasingly, in terms of scientific construction, continue to implement and broad. By private colleges and joint development of cultural creative industrial park, provides external help to private colleges and universities to improve their own problems.

\section{Conclusion}

Culture creative industry rapid rise, making the existing human resources appeared the shortage of corresponding or not. In this background, art the cultivation of innovative talents has become the social focus. This paper mentioned a number of private colleges and universities personnel training problem is widespread, not a special case of the individual schools, strengthen strategy is proposed to solve these problems have certain feasibility. Hope to help national art innovative talent training plan.

\section{Reference}

[1] Dong Yan. Under the background of cultural creative industry development in henan university study of the innovative talents training, J. News study Tribune, 6(2015) 21-23.

[2] Yaodong $\mathrm{Xu}$, Xiaofeng Shao. Creative talent training is the key to the cultural creative industries, in the art design education in colleges and universities, for example, J. Fujian BBS (humanities and social science edition), 6(2015) 56-58.

[3] Xiaoxi li. Culture creative industry talents training research colleges and universities, D. Shanghai university, 2014. 